\title{
Evaluation of Anti-Infectives on Acute Respiratory Infection in Patients at Three Primary Health Cares Centres in Depok, Indo- nesia
}

\author{
Alya Zahra Syahidah, Retnosari Andrajati, Atika Wahyu Puspitasari \\ Clinical Pharmacy Department, Pharmacy Faculty, Universitas Indonesia, Depok 16424, West Java, INDONESIA.
}

\begin{abstract}
Introduction: The high prevalence of Acute Respiratory Infection (ARI) in Indonesia can increase anti-infective use and affect their patterns of use. Objective: This study aimed to evaluate anti-infective use in 2015 at 3 primary health care centres, Limo Primary Health Care (LPHC), Bojongsari Primary Health Care $(\mathrm{BPHC})$, and Cipayung Primary Health Care ( $\mathrm{CPHC})$. Material and methods: This study was descriptive analytic research using retrospective data. Samples consisted of 20,441 ARI patients' prescriptions containing anti-infective drugs during 2015. Anti-infective drugs were classified using the anatomical therapeutic chemical (ATC) classification system. Drug use was measured as Daily Defined Dose (DDD)/1000 patients/day. Drug use 90\% and adherence to the National Formulary was evaluated as an indicator of the quality of prescribing drugs. Results: The highest amount of anti-infective use for ARI patients was at $\mathrm{CPHC}$ with a total quantity of $0.95 \mathrm{DDD} / 1000$ patient/day. While at the LPHC amount of anti-infective use was 0.76 DDD/1000 patients/day and at $\mathrm{BPHC}$ was only $0.65 \mathrm{DDD} / 1000$ patients/day. The most anti-infectives use at all primary health cares was amoxicillin. Ten anti-infectives were use at LPHC, 11 at BPHC and 7 at CPHC. Anti-infectives in the DU $90 \%$ segment at LPHC
\end{abstract}

were amoxicillin, co-trimoxazole, and cefadroxil while amoxicillin was the only DU90\% anti-infective used at $\mathrm{CPHC}$ and $\mathrm{BPHC}$. The adherence to National Formulary were $70.00 \%$ at $\mathrm{LPHC}, 71.43 \%$, at $\mathrm{BPHC}$, and $63.64 \%$ at $\mathrm{CPHC}$. Conclusion: The use of anti-infective varied and it showed that some did not adhere to National Formulary guidelines.

Key words: Adherence, Anti-infective, ATC/DDD, National Formulary, Primary health care

\section{Correspondence:}

Retnosari Andrajati

Clinical Pharmacy Department, Pharmacy Faculty, Universitas Indonesia, Depok 16424, West Java, INDONESIA.

Phone no: 62217270031

Email: andrajati@farmasi.ui.ac.id

DOI: 10.5530/jyp.2017.1s.9

\section{INTRODUCTION}

The prevalence of acute respiratory infection (ARI) in Indonesia was $25.0 \%$ in 2013 , similar to $25.5 \%$ in $2007 .{ }^{1}$ ARI was the most common infection according to the classification of outpatient illness cases at primary health care centres in Depok for the 0-44 year age range. ARI was the second most common illness for the age range of 45->75 years after cases of primary hypertension. ${ }^{2}$

The high prevalence of ARI in Indonesia can increase anti-infective use and affect their patterns of use. In addition, excessive use of antiinfectives may increase the resistance incidence. Therefore, evaluation of the quantity and quality of anti-infective usage is required to improve its rationality. The World Health Organisation (WHO) has suggested an evaluation of drug use utilising the Anatomical Therapeutic Chemical (ATC) Classification System and Defined Daily Doses (DDD) as a measure of drug use. ${ }^{3}$ ATC/DDD methods were employed to study drug use to improve the quality of drugs use. ${ }^{4}$

This study aimed to evaluate anti-infective use at 3 primary health care centres, Limo Primary Health Care (LPHC), Bojongsari Primary Health Care (BPHC), and Cipayung Primary Health Care(CPHC). This evaluation covers DU90\% and adherence to the National Formulary as an indicator of the quality of prescribing drugs.

\section{MATERIALS AND METHODS}

This study was descriptive analytic research. The data used were retrospective data consisting of recapitulation data of anti-infective prescriptions on ARI patients at 3 primary health care centres in Depok from
January to December 2015 and were taken from the Drug Management Information System (DMIS) and Management Information Systems Primary Health Care (MISPHC). The data were collected between February and May 2016. Samples were the patients' prescriptions that had a disease code for ARI with inclusion criteria of prescriptions containing anti-infective given orally; data were excluded if the prescriptions were illegible or did not have the disease code.

Anti-infective drugs were classified using the anatomical therapeutic chemical (ATC) classification system. Drug use was measured as Daily Defined Dose (DDD)/1000 patients/day. Measurement of quantitative data was accomplished by classifying anti-infective based on the ATC code and converting the quantity of anti-infective use into DDD units. ${ }^{4}$ In addition, the adherence of anti-infective use to National Formulary standards was evaluated as an indicator of the quality of use.

\section{RESULTS}

\section{The Quantity of Drug use}

The highest amount of anti-infective usage for ARI patients was at CPHC; anti-infective use involved 11 medication types with a total quantity of $0.95 \mathrm{DDD} / 1000$ patient/day. The amount of anti-infective use was lower at LPHC than CPHC; the quantity reached only $0.76 \mathrm{DDD} / 1000$ patients/day of 10 anti-infective types being used. The amount of antiinfective use at BPHC was the lowest of the 3 centres and was only 0.65 
DDD/1000 patients/day of 7 anti-infective types being used. The amount of DDD/1000 patients/day for each centre is shown in Table 1.

Amoxicillin was the most frequently used anti-infective for ARI therapy at each centre. The highest amoxicillin use was at $\mathrm{CPHC}$ at a statistical amount of $0.98 \mathrm{DDD} / 1000$ patients/day, meaning that $0.09 \%$ of the total patients per day at CPHC were prescribed amoxicillin. The quantity of amoxicillin use at BPHC was much lower, reaching only $0.59 \mathrm{DDD} / 1000$ patients/day, meaning that only $0.058 \%$ of amoxicillin per day was prescribed to patients at BPHC. Meanwhile, the lowest quantity of amoxicillin usage occurred at LPHC, $0.2816 \mathrm{DDD} / 1000$ patients/day, which meant that only $0.028 \%$ patients per day were prescribed amoxicillin.

\section{The quality of drugs used}

The anti-infection forming DU 90\% segment can be seen on Figure 2. Ten anti-infectives were use at LPHC, 11 at BPHC and 7 at CPHC. Anti-infectives in the DU 90\% segment at LPHC were amoxicillin, cotrimoxazole, and cefadroxil while amoxicillin was the only DU90\% antiinfective used at CPHC and BPHC.

The adherence percentage of antiinfection usage to national formulary was shown in Table 2. At LPHC, the adherence of anti-infective usage on ARI patients was $70.00 \%$ and non-adherence was $30.00 \%$, as cefadroxil, cefixime, and thiamphenicol were not in accordance with the National Formulary. At CPHC, the adherence of anti-infective use on ARI patients was smaller compared to LPHC; it had only $63.64 \%$ adherence while non-adherence reached $36.36 \%$ since cefadroxil, thiamphenicol, and azithromycin were not in accordance with the National Formulary. BPHC had the highest adherence at $71.43 \%$ with non-adherence only $28.57 \%$; this was due to the useof cefadroxil and levofloxacin, which were not in accordance with the National Formulary.

\section{DISCUSSION}

The quantity of anti-infective use could not be compared according to DDD statistical amounts due to the difference in healthcare service hours at 1 of the primary health care centres being observed. This ultimately led to a condition in which the total amount of anti-infective usage at 1 primary health care facility was so different from the other 2 primary health care centres that the quantity of anti-infective usage was computed using $\mathrm{DDD} / 1000$ patients/day in order to compare its value to each primary health care centre. ${ }^{4}$

The quantity of anti-infective use in ARI patients at CPHC, LPHC, and BPHC in 2015 showed various differing amounts (Figure 1), either the DDD statistical amount or the number of drug types. CPHC had the highest use of anti-infectives in 2015 compared to the 2 other centres because it performed services 24 hours a day. The quantity of anti-infective use at BPHC and LPHC was nearly the same, at $0.65 \mathrm{DDD} / 1000 \mathrm{pa}$ tients/day and $0.76 \mathrm{DDD} / 1000$ patients/day, respectively.

Due to its wide spectrum, amoxicillin was used at $70.30 \%$ to relieve respiratory tract and other infections. ${ }^{5}$ It was not surprising that amoxicillin was the most frequently used anti-infective for ARI therapy at each centre in this study. The results of this study were in agreement with Retnosari's finding in 2012 indicating that amoxicillin was the most frequently presribed antibiotic in eleven primary health centers in Depok. ${ }^{6}$ However ampicillin was the most frequently antibiotic at six primary health centers in South Sumatra, Indonesia.

Although amoxicillin was the most frequently use at at three primary health centers in this study however, the quantity of amoxicillin use was quite different $0.98 \mathrm{DDD} / 1000$ patients/day, $0.59 \mathrm{DDD} / 1000$ patients/ day, $0.28 \mathrm{DDD} / 1000$ patients/day respectively (Figure 1). Small quantity of amoxicillin use at two others primary health centers probably could be explain by the finding of previous study ${ }^{6}$ that duration of antibiotic administration was frequently too short. Similar to quantity of amoxicillin at CPHC in our finding, a study at Krishna Hospital in India showed that $0.8942 \mathrm{DDD} / 1000$ patients/day of amoxicillin were used for medical therapy of upper respiratory tract infections. ${ }^{8}$

Amoxicillin was the only DU90\% anti-infective used at CPHC and BPHC. Neither of these centres used ampicillin since it has the same indicationas amoxicillin; these centres tended to use amoxicillin, which has been widely employed for ARI therapy and is categorised in the DU90\% segment. Observational studies in community health service centres in the North Gorontalo Districtalso showed that amoxicillin was the antiinfective used on non-pneumonia ARI patients at all primary health care centres there;it is included in DU90\%. ${ }^{9}$

Table 1: Anti-infection use rate at three primary health cares

\begin{tabular}{|c|c|c|c|c|c|c|c|}
\hline \multirow{3}{*}{ Anti-infection } & \multirow{3}{*}{ ATC code } & \multicolumn{2}{|c|}{ Limo } & \multicolumn{2}{|c|}{ Cipayung } & \multicolumn{2}{|c|}{ Bojongsari } \\
\hline & & \multicolumn{2}{|c|}{ Primary Health Care } & \multicolumn{2}{|c|}{ Primary Health Care } & \multicolumn{2}{|c|}{ Primary Health Care } \\
\hline & & DDD & $\begin{array}{c}\text { DDD/1000 } \\
\text { patients/day }\end{array}$ & DDD & $\begin{array}{c}\text { DDD/1000 } \\
\text { patients/day }\end{array}$ & DDD & $\begin{array}{c}\text { DDD/1000 } \\
\text { patients/day }\end{array}$ \\
\hline Amoksisilin & J01CA04 & 3294.00 & 0.2816 & 19114.00 & 0.8792 & 7058.75 & 0.5894 \\
\hline Ampisilin & J01CA01 & 230.00 & 0.0197 & - & - & - & - \\
\hline Asiklovir & J05AB01 & 3.90 & 0.0003 & 7.40 & 0.0003 & 3.00 & 0.0003 \\
\hline Azitromisin & J01FA10 & - & - & 8.33 & 0.0004 & - & - \\
\hline Dosisiklin & J01AA02 & 15.00 & 0.0013 & 10.00 & 0.0005 & - & - \\
\hline Eritromisin & J01FA01 & 37.50 & 0.0032 & 35.00 & 0.0016 & 120.00 & 0.0100 \\
\hline Kloramfenikol & J01BA01 & - & - & 5.83 & 0.0003 & - & - \\
\hline Kotrimoksazol & J01EC01 & 3243.90 & 0.2773 & 647.28 & 0.0298 & 176.64 & 0.0147 \\
\hline Levofloksasin & J01MA12 & - & - & - & - & 5.00 & 0.0004 \\
\hline Sefadroksil & J01DB05 & 1118.25 & 0.0956 & 581.75 & 0.0268 & 171.00 & 0.0143 \\
\hline Sefiksim & J01DD08 & 155.75 & 0.0133 & 90.00 & 0.0041 & - & - \\
\hline Siprofloksasin & J01MA02 & 765.00 & 0.0654 & 100.00 & 0.0046 & 230.00 & 0.0192 \\
\hline Tiamfenikol & J01BA02 & 15.33 & 0.0013 & 43.67 & 0.0020 & - & - \\
\hline Total & 8878.63 & 0.7590 & 20643.26 & 0.9496 & 7764.39 & 0.6483 & \\
\hline
\end{tabular}


Table 2: The Adherence to National Formulary

\begin{tabular}{cccc}
\hline Description & LPHC & CPHC & BPHC \\
\hline Adhere & $7(70.00 \%)$ & $7(63.64 \%)$ & $5(71.43 \%)$ \\
Not adhere & $3(30.00 \%)$ & $4(36.36 \%)$ & $2(28.57 \%)$ \\
Total & $10(100 \%)$ & $11(100 \%)$ & $7(100 \%)$ \\
\hline
\end{tabular}

LPHC: Limo Primary Health Care

CPHC: Cipayung Primary Health Care

BPHC: Bojongsari Primary Health Care

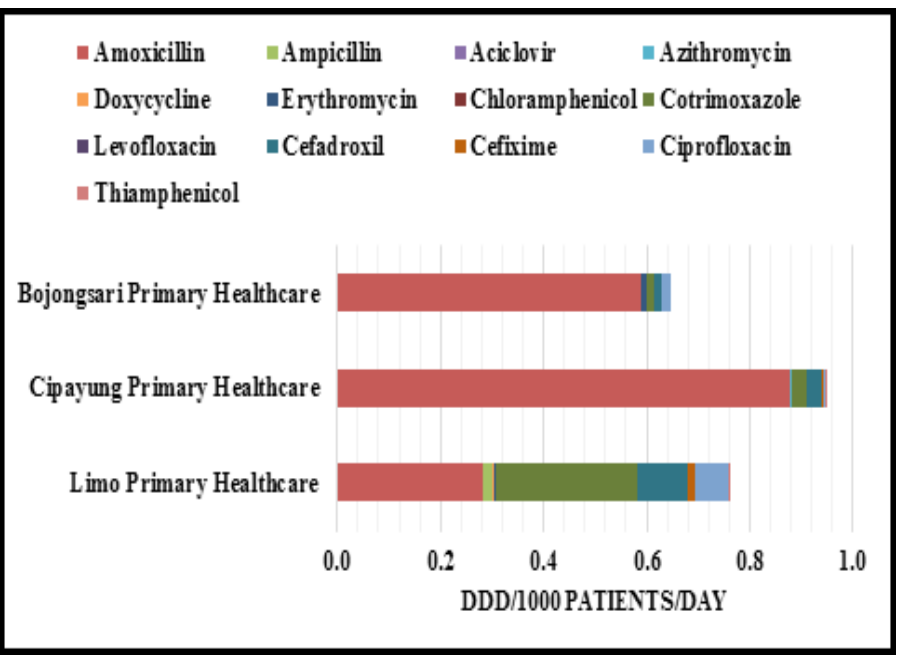

Figure 1: Value of $\mathrm{DDD} / 1000$ patients/ day.

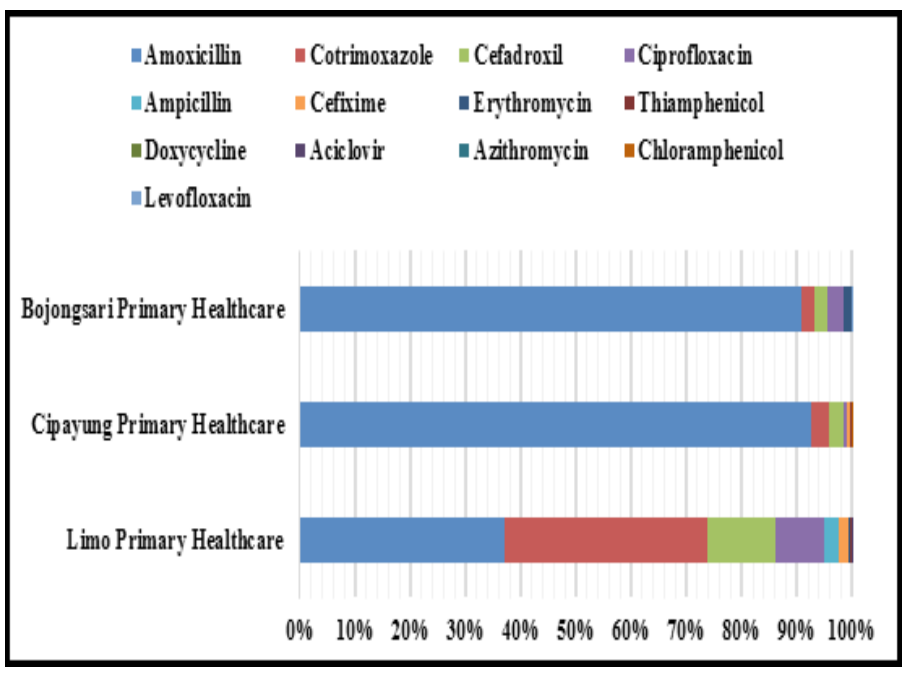

Figure 2: Anti-infection that form DU 90\%.

Anti-infectives in LPHC were amoxicillin (J01CA04), co-trimoxazole (J01EC01), and cefadroxil (J01DB05). Amoxicillin had a $37.10 \%$ usage percentage at LPHC. Anti-infectives with the same indication as amoxicillin were also used at LPCH, namely ampicillin. The antiinfection forming DU 90\% segment can be seen on Figure 2. Another drug classified as DU90\% at LPHC was co-trimoxazole (sulfonamide group). which is a combination of 2 kinds of drugs, trimethoprim and sulfamethoxazole, which have a wide spectrum;this drug can be used as the empiric therapy for various kinds of infections. Various research has proven the effectiveness of co-trimoxazole indecreasing fatality and sickness rates by reducing the incidence of infections caused by bacteria. ${ }^{10}$ This is the same as research conducted in 2015 monitoring the use of antibiotics at Abepura Hospital in Jayapura. Results indicated that cotrimoxazole is in the first rank of the DU90\% segment. ${ }^{11}$

Cefadroxil was another DU90\% anti-infective used on ARI patients at LPHC, although in small quantities. Cefadroxil is an antibacterial utilised for systemic consumption; it belongs to the beta-lactam group and is commonly used in infection therapy. In 2010, cefadroxil was included in 18 types of DU90\% antibiotics according to previous research. ${ }^{12}$

The quality of drug use was measured by analysing the adherence of drug use with the list of drugs inthe National Formulary. The use of the National Formulary as the guideline for drug usage is an effort to assure rational and appropriate drug consumption. ${ }^{13}$

At LPHC, the adherence of anti-infective usage on ARI patients was $70.00 \%$ and non-adherence was $30.00 \%$, as cefadroxil, cefixime, and thiamphenicol were not in accordance with the National Formulary. At CPHC, the adherence of anti-infective use on ARI patients was smaller compared to LPHC; it had only $63.64 \%$ adherence while non-adherence reached $36.36 \%$ since cefadroxil, thiamphenicol, and azithromycin were not in accordance with the National Formulary. BPHC had the highest adherence at $71.43 \%$ with non-adherence only $28.57 \%$; this was due to the useof cefadroxil and levofloxacin, which were not in accordance with the National Formulary .

Anti-infectives used on ARI patients at LPHC that were not in accordance with the National Formulary since they were not intended for a primary health center or were not listed in the National Formulary included cefadroxil (J01DB05) and cefixime(J01DD08), which are firstand third-generation cephalosporins. These anti-infectives were also used at CPHC, while BPHC used only cefadroxil. However, cefadroxil and cefixime were on the WHO's Essential Medicines List of 2013. Cefadroxil and cefixime were used by LPHC and cefadroxil was used by BPHC.

LPHC used thiamphenicol as an alternative anti-infective even though it is not in accordance with the National Formulary. However, it was in the Basic Treatment Guidelines in Primary Health Care 2007,so it was used. CPHC used thiamphenicol as an anti-infective on ARI patients, but CPHC also used chloramphenicolas an anti-infective for ARI therapy.

CPHC also used azithromycin (J01FA01), which is not listed in the National Formulary but is mentioned in the Basic Treatment Guidelines in Primary Health Care 2007. LPH and BPHC preferred to use erythromycin (J01FA01) as it is listed in the National Formulary.

Non-adherence of the anti-infective usage on ARI patients also occurred at BPHC. The quinolone group has the same indication as ciprofloxacin (J01MA02) and levofloxacin (J01MA12). Levofloxacin is not mentioned in the National Formulary for primary health centre, National Essential Medicines List (DOEN) 2013, or in the Basic Treatment Guidelines in Primary Health Care 2007. Levofloxacin was not used by LPHP and BPHP as they preferred ciprofloxacin, which has the same indication as levofloxacin and is listed in the National Formulary. Table 2 contains details about the adherence of anti-infective use at CPHC, LPHC, and BPHC.

The use of anti-infectives on ARI patients according to DDD/1000 patients/day from the highest rank to the lowest rank was CPHC, LPHC, and BPHC. The DU90\% anti-infectives used on ARI patients at LPHC were amoxicillin, co-trimoxazole, and cefadroxil, while amoxicillin was used at CPHP and BPHC. The adherence percentage of use of anti-infectives that conformed to National Formulary standards from the highest to the lowest was BPHP, LPHP, and CPHP.

\section{CONCLUSION}

The use of anti-infectives at CPHC, LPHC, and BPHC varied and some did not adhere to National Formulary guidelines. 


\section{ACKNOWLEDGMENTS}

Funding for this study was provide by Universitas Indonesia.

\section{CONFLICT OF INTEREST}

No conflict of interest are declare.

\section{ABBREVIATIONS USED}

ARI: Acute Respiratory Syndrome; LPHC: Limo Primary Health Care; BPHC: Bojongsari Primary Health Care; CPHC: Cipayung Primary Health Care; ATC: Anatomical Therapeuticc Chemical; DDD: Daily Defined Dose.

\section{REFERENCES}

1. Simoes EAF, Bregman U, Lahon K, Naik HG, Olveira G, Sjoqvist F, et al. Acute Respiratory Infection in Children. Desease Control Priorities in Developing Countries $2^{\text {nd }}$ Edition.New York: Oxford University Press; 2006.

2. Department of Health Depok City. Profil Kesehatan Kota Depok Tahun 2013 Depok: Department of Health Depok City; 2014.

3. World Health Organization. Guideline for ATC Classification and DDD Assignment 2016. Oslo: WHO Collaborating Centre for Drug Statistics Methodology: 2015. Available from www.whocc.no.

4. World Health Organization. Introduction to Drug Utilization Research.Geneva: World Health Organization; 2003. Available from http://apps.who.int/medicined- ocs/pdf/s4876e/s4876e.pdf.

5. Ramachandra N, Sanji N, Somashekar HS, Acharya A, Sagar K, Halemani S. Trends in Prescribing Antimicrobials in an ENT Outpatient Department of Tertiary Care Hospital for Upper Respiratory Tract Infections. Int J Pharmacol and Clin Sci, 2012;1(1):15-8

6. Andrajati R, Tilaqza A, Supardi S. factors related to rational antibiotic prescriptions in community health centers in Depok City, Indonesia. J Infect Public Health 2017;10(1):41-8. https://doi.org/10.1016/j.jiph.2016.01.012; PMid:26952648.

7. Munaf S. Antibiotic prescription habit in six primary health centres in South Sumatra. Med J Indones. 2005;14(1):44-9. https://doi.org/10.13181/mji.v14i1.170.

8. Naik HG, Khanwelkar CC, Kolur A, Desai R, Gidamudi S. Drug Utilization Study on Antibiotics Use in the Upper Respiratory Tract Infection. International Journal of Recent Trends in Science and Technology. 2014;10(12):299-302.

9. Pani S, Barliana MI, Halimah E, Pradipta IS, Annisa N. Monitoring Penggunaan Antibiotik dengan Metode ATC/DDD dan DU 90\% : Studi Observasional di SeIuruh Puskesmas Kabupaten Gorontalo Utara. Jurnal Farmasi Klinik Indonesia, 2015;4:275-80.

10. Directorate General of Disease Control and Environmental Health. Panduan Tatalaksana Klinis Infeksi HIV pada Orang Dewasa dan Remaja, Edisi Kedua. Jakarta: Department of Health of the Republic of Indonesia; 2007.

11. Hasrianna, Annisa N, Milanda T, Pradipta IS, Abdulah R. Monitoring Penggunaan Antibiotik dengan Metode ATC/DDD dan DU 90\% di RSUD Abepura Jayapura Indonesia. Jurnal Farmasi Klinik Indonesia, 2015;4:218-25.

12. Pradipta IS, Febrina E, Ridwan MH, Ratnawati R. Identifikasi Pola Penggunaan Antibiotik sebagai Upaya Pengendalian Resistensi Antibiotik. Indones J Clin Pharm, 2012;1:16-24

13. Health Minister of the Republic Indonesia. Keputusan Menteri Kesehatan Republik Indonesia Nomor 328/Menkes/SKNIII/2013 tentang Formularium Nasional. Jakarta: Ministry of Health of the Republic of Indonesia; 2013.

Article History: Submission Date: 20-01-17; Revision Date: 21-01-17; Accepted Date:14-02-17.

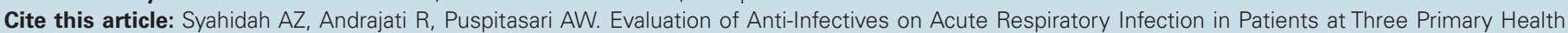
Cares Centres in Depok, Indonesia. J Young Pharm. 2017;9(1)Suppl:s35-s8. 